\title{
Biosaintifika
}

Journal of Biology \& Biology Education

http://journal.unnes.ac.id/nju/index.php/biosaintifika

\section{The Effect of Bacteria Colony Pseudomonas fluorescens (UB_Pf1) and Bacillus subtilis (UB_Bs1) on the Mortality of Pratylenchus coffeae (Ty- lenchida: Pratylenchidae)}

\author{
${ }^{\otimes}$ Presti Mardiyani Purwaningtyas ${ }^{1}$, Bambang Tri Rahardjo $^{2}$, Hagus Tarno $^{2}$
}

DOI: 10.15294/biosaintifika.v8i3.5067

${ }^{1}$ Plant Science Program, Graduate School of Agriculture, Universitas Brawijaya, Malang, Indonesia ${ }^{2}$ Department of Plant Pests and Diseases, Faculty of Agriculture, Universitas Brawijaya, Malang, Indonesia

\section{History Article}

Received 15 February 2016

Approved 30 July 2016

Published 24 December 2016

\section{Keywords:}

Bacillus subtilis (UB_Bs1); Median Lethal Concentration; Median Lethal Time; Pseudomonas fluorescens (UB_ Pf1); Pratylenchus coffeae

\begin{abstract}
Parasitic Root-Lession nematode of Pratylenchus coffeae can reduce the Indonesian coffee plants productivity. Several studies reported that Pseudomonas fluorescens and Bacillus subtilis endophytic bacteria were antagonistic bacteria to nematode. The objective of this research was to reveal the effectiveness of bacterial colonies density of P. fluorescens (UB_Pf1), B.subtilis (UB BS1), and a combination of both bacteria on nematode mortality using median lethal concentration $\left(\mathrm{LC}_{50}\right)$ and median lethal time $50\left(\mathrm{LT}_{50}\right)$. The densities of bacteria used in this study were $10^{7}, 10^{9}, 10^{11}$ and $10^{13} \mathrm{cfu} / \mathrm{ml}$. 35 testing nematodes were used and the mortality was counted at 6,12 , 24,36 , and 48 hours after treatments. The results showed that $\mathrm{LC}_{50}$ values of $P$. fluorescens was (UB_Pf1) was $4,3 \times 10^{8} \mathrm{cfu} / \mathrm{ml}, \mathrm{LC}_{50}$ B. subtilis (UB_Bs1) was $1,9 \mathrm{x} 10^{9} \mathrm{cfu}$ / $\mathrm{ml}$, and $\mathrm{LC}_{50}$ combination of both bacteria was, $8 \times 10^{7} \mathrm{cfu} / \mathrm{ml}$. It implies that the application of the combination of both bacteria are more pathogenic than single bacterial treatment. The results also showed that the highest $\mathrm{LT}_{50}$ value was 13.21 hours combination of bacterial colonies with a density of $10^{13} \mathrm{cfu} / \mathrm{ml}$ and the lowest $\mathrm{LT}_{50}$ value was 52.00 hours on P. fluorescens (UB_Pf1) treatment with colonies density of $10^{7} \mathrm{cfu} / \mathrm{ml}$.
\end{abstract}

\section{How to Cite}

Purwaningtyas, P. M., Rahardjo, B. T., \& Tarno, H. (2016). The Effect of Bacteria Colony Pseudomonas fluorescens (UB_Pf1) and Bacillus subtilis (UB_Bs1) on the Mortality of Pratylenchus coffeae (Tylenchida: Pratylenchidae). Biosaintifika: Journal of Biology \& Biology Education, 8(3), 286-293.

(C) 2016 Universitas Negeri Semarang $\bowtie$ Correspondence Author:

J1. Veteran, Malang 65145, Indonesia

E-mail: presti_rena@yahoo.co.id
p-ISSN 2085-191X e-ISSN 2338-7610 


\section{INTRODUCTION}

Productivity of coffee plants in Indonesi as considered low compared to the main producer countries in the world. One of the causes is the main OPT of parasitic nematode on coffee. The related parasitic nematode that infests almost the whole coffee plantation in Indonesia is the rootlesion nematode of Pratylenchus coffeae. The nematode infestation has disturbed the plant growth and production, both quantity and quality.

According to Wiryadiputra (1998), infestation of $P$. coffea on Robusta coffee could reduce production ranged $28.73 \%-78.45 \%$ or the average of production reduction is about $56.85 \%$. The nematode control has still applied nematicide. Chemical control using nematicide is costly and may create poisonous effect. Besides, greater demand for organic coffee and specialty coffee in the global market, which are safe for human health, are cost higher than the conventional coffee. Therefore, an environmental-friendly method is required as an alternative controlling method. Bacteria are one of organism found abundantly in the soil and has a great potential as bioagent to control nematode, as shown by several genus such as Pasteuria, Pseudomonas, and Bacillus (Emmert \& Handelsman, 1999; Siddiqui \& Mahmood, 1999).

Bacteria from Bacillus spp. And Pseudomonas spp. genus are antagonist to nematode and have the greatest population in rhizosphere (Krebs et al., 1998). Thus, this research aimed to reveal $\mathrm{LC}_{50}$ and $\mathrm{LT}_{50}$ value of bacteria collection from Plant Pest and Disease Department, Brawijaya University, Pseudomonas fluorescens (UB_Pf1) and Bacillus subtilis (UB_Bs1) on P. coffeae. Furthermore, the result of this research can be used as references to conduct other researches.

\section{METHODS}

This research was conducted at Nematology Laboratory, Plant Pest and Disease Department, Faculty of Agriculture, University of Brawijaya, from January to March 2015. The equipments used were Baermann's funnel, Baermann's funnel rack, host tweezers, nematode strainer, petri dish, pincers, fishhook needle, micropipette, microscope, hand counter, calibrated beaker, hand sprayer, and other supporting tools. Materials of the research included nematode isolates of P.coffeae; bacterial isolate of $P$. fluorescens (UB_Pf1) and B. subtilis (UB_Bs1).

Nematode exploration was done through extraction on coffee's roots infected by nematode using Baermann's funnel method. The infected roots, which were infested by $P$. coffeae nematode, were rinsed thoroughly. Then, they were cut into pieces before they were put on the screening paper that had been previously watered until the whole roots sub merged for $2 \times 24$ hours. When suspension containing nematode was obtained, then it was observed using microscope. Lastly, the discovered nematode was hooked in order to be identified by Morphometry technique.

The bacterial isolates used in this research were $P$. fluorescens (UB_Pf1) and B. subtilis (UB_ Bs1), collections from Plant Pest and Disease Department, Faculty of Agriculture, Brawijaya University. Propagation of both bacteria was done using sterile aqua. The formed bacterial colonies were suspended into sterile water and then they were shook for 24 hours using shaker in order to obtain appropriate concentration of the bacterial colonies density. Several density treatments used were $10^{7}, 10^{9}, 10^{11}$, and $10^{13} \mathrm{cfu} / \mathrm{ml}$. Measurement of the absorbent values used spectrophotometer $\left(\mathrm{OD}_{600}=1\right)$.

The research was conducted by applying appropriate bacterial suspension with a given concentration in a petri dish, which had been inoculated with 35 infective juvenile $P$. coffeae. The observation on mortality of $P$. coffeae was done at 6 , $12,24,36$, and 48 hours after the treatment (hat). The nematode mortality was counted, and then counting the percentage of its mortality. If the control treatment found the mortality less than $20 \%$, the corrected mortality must be counted.

Median Lethal Concentration $\left(\mathrm{LC}_{50}\right)$ is concentration of bacterial colonies density that causes the nematode mortality reached $50 \%$ based on the statistical calculation. While, Median Lethal Time $\left(\mathrm{LT}_{50}\right)$ is duration of exposure required by bacteria to reach $50 \%$ nematode mortality, which is determined by probit analysis method using a software of Hsin Chi Probit Analysis program (Chi, 1997).

\section{RESULTS AND DISCUSSIONS}

\section{The result of nematode identification roots of coffee plant}

The objective of the identification process in this research was to confirm the testing nematode, $P$. coffeae. The results of identification using the morphometry were showed in the following Figure 1, 2, 3.

Based on the identification, the results showed that the parasitic nematode on the coffee roots included in P. coffeae. It could be found from morphometry results and then compared them to the literatures. According to Loof (1949), P. cof- 
feae is marked by two annuls on the labium area, body length $0.37-0.83 \mathrm{~mm}$, the anterior part is dome-shaped. Also, there is a spermatheca that

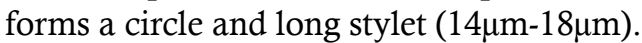

According to Siddiqui (1972), female $P$. coffeae has slim shape on younger juvenile and fatter shape on the mature ones. Nematode's body shows noticeable annulations. In general, the lateral part is divided into four sections, but some of them may be divided into five or six sections. The mouth part has two noticeable annulations. On young female, length of the tail is 2-2.5 times of the body width or 1.5-2 times on the mature female.

If it is compared to some nematode photographs, Mullin (2000) suggested that the nematode also has some similarities in body shape, stylet, basal knob, and the tail. Therefore, it can a)

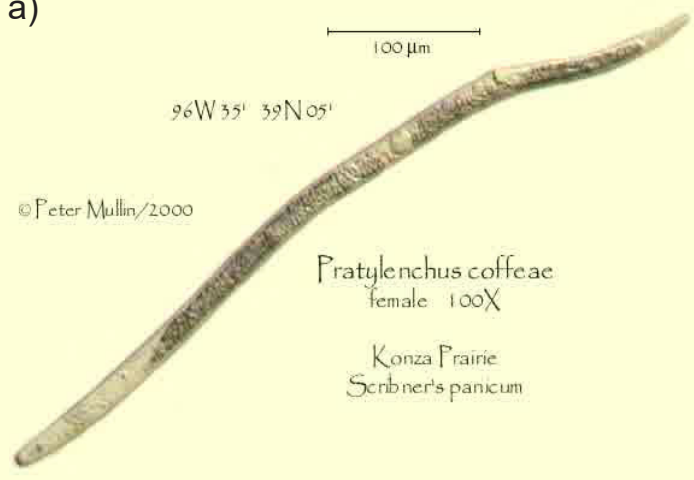

b)

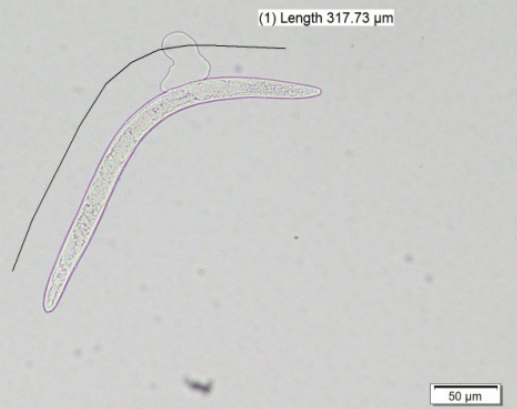

Figure 1. a) P. coffeae nematode (Mullin, 2000); b) P. Coffeae nematode found at the coffe plant root (100x magnification)

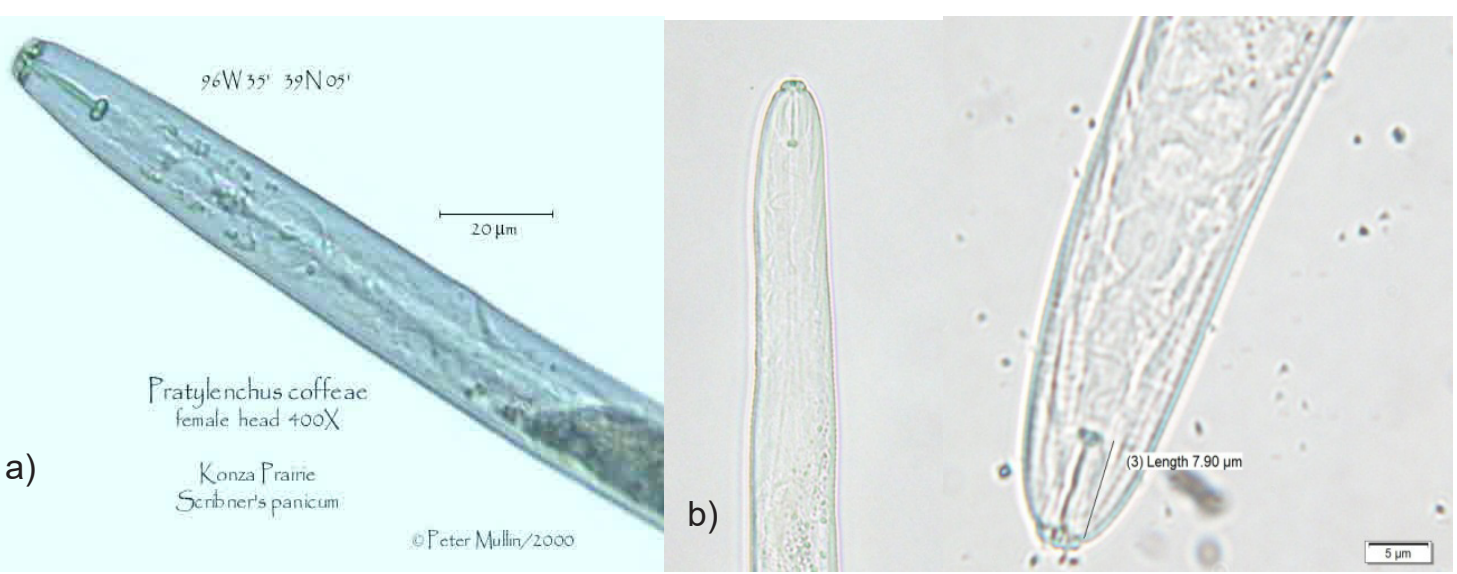

Figure 2. a) P. coffeae stylet (Mullin, 2000); b) Nematode stylet (400x magnification)
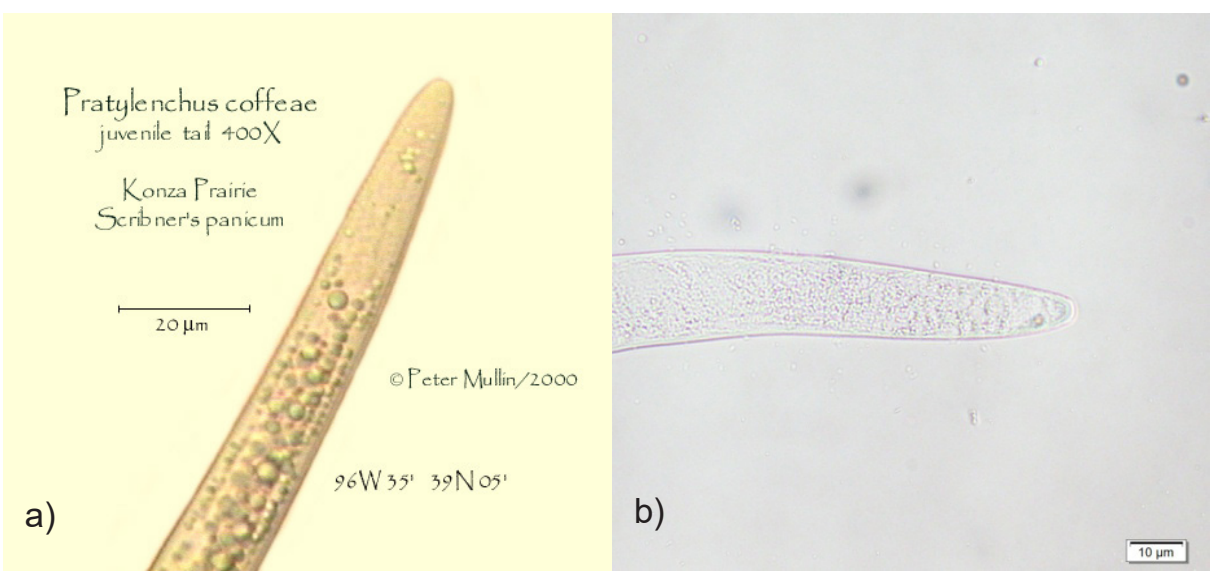

Figure 3. a) P. coffeae tail (Mullin, 2000); b) Nematode (400x magnification) 
be concluded that the nematode found included in $P$. coffeae species.

\section{The effect of bacterial isolates on percentage of nematode mortality}

Based on the results of the analysis of variance test, percentage of nematode mortality showed significant differences on all levels of bacterial colonies density and all intervals of time during observations. Mean percentage of the corrected mortality of nematode on each treatment and time interval of observation were presented in Table 1.

The percentage of the corrected mortality of testing nematode, as presented in Table 1 , can be clearly seen in Figure 4. The graphic showed that the testing nematode mortality trend increases along with the length of observation duration. Table 1 and Figure 4 showed that a significant effect of bacterial application on nematode mortality occurred at the entire time of observation started from the first observation (6 hours after application). During the observation, several levels of the applied bacterial colonies density showed a significant effect among treatments. Percentage of the highest mortality was found on the application of both bacterial combinations with the colonies density $10^{11} \mathrm{cfu} / \mathrm{ml}(23.81 \%)$, while the percentage of the lowest mortality was found on the application of bacteria $B$. subtilis with colonies density $10^{7} \mathrm{cfu} / \mathrm{ml}(4.72 \%)$.

The same thing was occurred on all observation intervals; the highest mortality occurred on application of both bacterial combination with colonies density $10^{13} \mathrm{cfu} / \mathrm{ml}$ and the percen- tage of the lowest mortality was occurred on the application of bacteria $B$. subtilis with colonies density $10^{7} \mathrm{cfu} / \mathrm{ml}$. Yet, for 24 hours observation after the treatment, UB_Pf1 treatment with colonies density $10^{7}$ showed the lowest mortality. In all of observation time, they showed the increasing percentage of mortality, which meant that the bacterial application affect nematode mortality instantly.

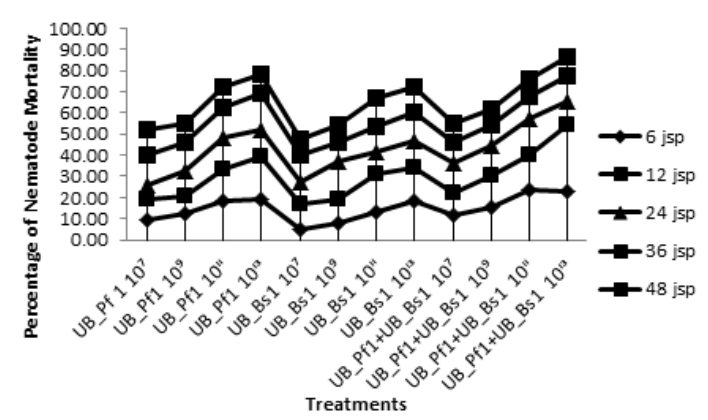

Figure 4. Correlation between concentration of the bacterial colonies density and the nematode mortality

During 36 hours treatment, it was found that UB_Pf1 treatment with the colonies densities $10^{7}$ and $10^{9}$, UB_Bs 1 with colonies densities $10^{7}$ and $10^{9}$, as well as the combination with colonies densities $10^{7}$ did not show significant differences. The increasing percentages of mortality still kept going on till the last observation (48 hours after the application) and showed high percentage reaching almost $90 \%$. It implies that the bacteria can suppress population of the nematode.

In general, it was found out that bacteria

Table 1. Mean percentage of corrected mortality (\%) P. coffeae at laboratory

\begin{tabular}{|c|c|c|c|c|c|}
\hline \multirow[b]{2}{*}{ Treatment } & \multicolumn{5}{|c|}{ Corrected Mortality (\%) } \\
\hline & $\begin{array}{c}6 \text { haa } \\
(\bar{x} \pm S D)\end{array}$ & $\begin{array}{c}12 \text { haa } \\
(\bar{x} \pm S D)\end{array}$ & $\begin{array}{c}24 \text { haa } \\
(x+5 D)\end{array}$ & $\begin{array}{c}36 \text { haa } \\
(\bar{x} \pm S D)\end{array}$ & $\begin{array}{c}48 \text { haa } \\
(\bar{x}: \pm S D)\end{array}$ \\
\hline Control & $0.00 \pm 0.00$ & $0.00 \pm 0.00$ & $0.00 \pm 0.00$ & $3.33 \pm 1.97$ & $5.33 a \pm 0.59$ \\
\hline UB_Pf1 $10^{7}$ & $9.52 \pm 0.74 \mathrm{c}$ & $19.05 \pm 0.55 \mathrm{ab}$ & $25.71 \pm 0.82 \mathrm{a}$ & $33.75 \pm 1.35 \mathrm{a}$ & $43.91 \pm 4.53 \mathrm{ab}$ \\
\hline UB_Pf1 $10^{9}$ & $12.38 \pm 0.65 \mathrm{~d}$ & $20.95 \pm 1.06 \mathrm{ab}$ & $32.38 \pm 0.86 b$ & $39.94 \pm 2.65 \mathrm{a}$ & $47.20 \pm 0.44 \mathrm{bc}$ \\
\hline UB_Pf1 $10^{11}$ & $18.10 \pm 0.55 \mathrm{f}$ & $33.33 \pm 0.42 c$ & $48.57 \pm 0.62 \mathrm{ef}$ & $58.71 \pm 3.58 \mathrm{~cd}$ & $67.32 \pm 3.82$ ef \\
\hline UB_Pf1 $10^{13}$ & $19.05 \pm 0.55 \mathrm{f}$ & $39.05 \pm 1.41 \mathrm{de}$ & $52.38 \pm 1.52 \mathrm{fg}$ & $66.38 \mathrm{f} \pm 2.80 \mathrm{e}$ & $74.18 \pm 3.62 \mathrm{f}$ \\
\hline UB_Bs1 $10^{7}$ & $4.72 \pm 1.13 \mathrm{a}$ & $17.14 \pm 099 \mathrm{a}$ & $27.62 \pm 0.46 \mathrm{a}$ & $33.48 \pm 3.21 \mathrm{a}$ & $38.12 \pm 3.09 \mathrm{a}$ \\
\hline UB_Bs1 $10^{9}$ & $7.62 \pm 0.87 b$ & $19.05 \pm 0.55 \mathrm{ab}$ & $37.14 \pm 1.19 b c$ & $39.80 \pm 2.93 \mathrm{a}$ & $45.98 \pm 3.29 \mathrm{ab}$ \\
\hline UB_Bs1 $10^{11}$ & $13.33 \pm 0.65 \mathrm{de}$ & $31.43 \pm 0.75 \mathrm{c}$ & $41.91 \pm 0.02 \mathrm{~cd}$ & $48.25 \pm 2.69 b$ & $60.58 \pm 3.74 \mathrm{de}$ \\
\hline UB_Bs1 $10^{13}$ & $18.10 \pm 0.55 \mathrm{f}$ & $34.29 \pm 1.44 \mathrm{~cd}$ & $46.67 \pm 0.96 \mathrm{def}$ & $55.80 \pm 1.11 \mathrm{bc}$ & $67.47 \pm 2.31$ ef \\
\hline UB_Pf1+UB_Bs1 $\left(10^{7}\right)$ & $11.43 \pm 0.00 \mathrm{~cd}$ & $21.91 \pm 0.51 b$ & $36.19 \pm 0.41 b$ & $39.87 \pm 2.31 \mathrm{a}$ & $47.24 \pm 1.98 \mathrm{bc}$ \\
\hline UB_Pf1+UB_Bs $1\left(10^{\circ}\right)$ & $15.24 \pm 0.60 \mathrm{e}$ & $30.48 \pm 1.81 \mathrm{c}$ & $44.76 \pm 0.99 \mathrm{de}$ & $49.29 \pm 2.64 \mathrm{~b}$ & $55.02 \pm 2.07 \mathrm{~cd}$ \\
\hline UB_Pf1+UB_Bs1 $\left(10^{11}\right)$ & $23.81 \pm 0.48 \mathrm{~g}$ & $40.00 \pm 0.67 \mathrm{e}$ & $57.14 \pm 0.59 \mathrm{~g}$ & $64.17 \pm 1.08 \mathrm{de}$ & $71.88 \pm 1.30 \mathrm{f}$ \\
\hline UB_Pf1+UB_Bs1 $\left(10^{13}\right)$ & $22.86 \pm 0.86 \mathrm{~g}$ & $54.29 \pm 0.60 \mathrm{f}$ & $65.71 \pm 1.11 \mathrm{~h}$ & $74.84 \pm 3.05 \mathrm{f}$ & $84.29 \pm 1.08 \mathrm{~g}$ \\
\hline
\end{tabular}

Notes :

HAA: Hour After Application

Numbers followed by the same letter in the same column show insignificant difference based on Duncan test at level $5 \%$; data is transformed by equation $\arcsin \sqrt{\mathrm{x}}$ for statistical analysis purpose. 
that gave the greatest effect on nematode mortality were the combination of $P$. fluorescens and $B$. Subtilis with the highest density $10^{13} \mathrm{cfu} / \mathrm{ml}$. Application that had the lowest percentage was the application of $B$. subtilis with density $10^{7} \mathrm{cfu} / \mathrm{ml}$. It reveals that both bacteria are compatible when they are combined, so that their ability in suppressing population of nematode also increases. In line with Jetiyanon \& Kloepper's (2002) research suggested that the application of bacteria by combining several compatible bacterial strains and their antagonistic mechanism will provide greater suppressing effect in comparison with single application. Furthermore, the results of the test show that higher colonies density applied will be greater and faster in affecting nematode mortality.

\section{The effect of the bacterial isolates on median Lethal Concentration ( $\mathrm{LC}_{50}$ ) P. coffeae}

Based on the result of laboratory test, it showed that each bacterium in those treatments had diverse value of $\mathrm{LC}_{50} . \mathrm{LC}_{50}$ value, regression equation, and $\mathrm{R}^{2}$ of each treatment were presented in Table 2.

Data in Table 2 presented $\mathrm{LC}_{50}$ value on bacterial application of $B$. subtilis (UB_Bs1) $1,9 \times 10^{9} \mathrm{cfu} / \mathrm{ml}$. It meant that the bacterium was able to cause nematode mortality for almost $50 \%$ in 48 hours by applying bacteria that had colonies density $1.9 \times 10^{9} \mathrm{cfu} / \mathrm{ml}$. The results of data analysis showed that the regression equation on the treatment was $y=3.889+0.120 x$. It indicated that each increasing coefficient value $\mathrm{x}$ indicating the concentration, the coefficient value indicating the probitwould increase 3.889 . Testing on bacterium $P$. fluorescens (UB_Pf1) had $4.3 \times 10^{8}$ $\mathrm{cfu} / \mathrm{ml} \mathrm{LC}{ }_{50}$ value. The value implied that the bacterial colonies density as required by $P$. fluorescens (UB_Pf1) to exterminate nematode $50 \%$ in the same time was lower than the treatment $B$. subtilis (UB_Bs1). Value of the regression equation of UB_Bs1 was $y=3.747+0.145 x$. It indicated that each increasing coefficient value $\mathrm{x}$ (concentration), the coefficient value y (probit) would increase 3.747.

$\mathrm{LC}_{50}$ value on the combination of $P$. fluorescens (UB_Pf1) and B. subtilis (UB_Bs1) was $8.8 \times 10^{7}$. The result indicated that the combined bacterial application caused nematode mortality up to $50 \%$ in 48 hours by applying bacteria having colonies density $8.8 \times 10^{7} \mathrm{cfu} / \mathrm{ml}$. It implied that if the bacteria were, in the same time, applied in combination, they required lower colonies density compared to single application. Based on result of data analysis, the regression equation was $\mathrm{y}=$ $3.463+0.193 x$. It indicated that each increasing coefficient value $\mathrm{x}$ indicating the concentration, the coefficient value indicating the probit would also increase 3.463. Lower colonies density required might occur due to compatibility exists between both bacteria, so that it can increase their antagonistic to nematode, which is influential to the decreasing numbers of colonies density must be applied.

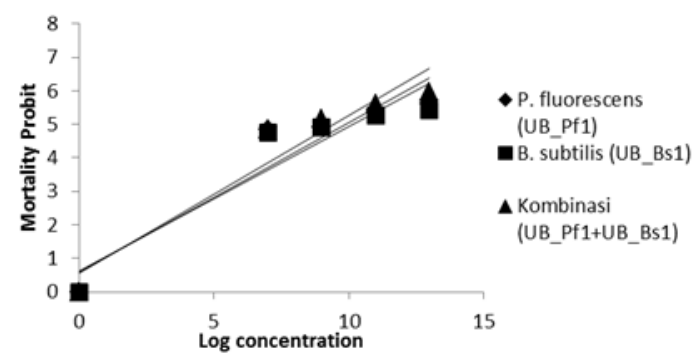

Figure 5. Correlation between concentration of the bacterial colonies density and the nematode mortality

Figure 5 showed the correlation between concentration of bacterial colonies density and testing nematode mortality. Based on the graphic, it presented that the bacterial colonies density had positive correlation on mortality which implied that the increasing bacterial colonies density would be followed by the increasing nematode mortality. It occurs due to the increasing colonies densities that leads to the antagonistic accumulation of the bacteria.

Bacillus is one of the bacterial genuses that could inhibit the spread of nematode (Kloepper \& Ryu, 2006). The same thing happened in bacteria of Pseudomonas groups, Bacillus has also produce secondary metabolites, and one of them is cytinase enzyme that could degrade the nematode cells. Research conducted by Harni, et al. (2010) reported that the bacterial endophyte isolates from Bacillus sp. genus is highly capable in suppressing population of nematode that cause root-lesion, $P$. brachyurus, on patchouli.

Table 2 . LC $_{50}$ value on $P$. coffeae nematode mortality

\begin{tabular}{llll}
\hline Bacterial type & $\mathrm{LC}_{50}$ value & Regression equation & $\mathrm{R}^{2}$ \\
\hline P. Fluorescens (UB_Pf1) & $4.3 \times 10^{8} \mathrm{cfu} / \mathrm{ml}$ & $\mathrm{y}=3.747+0.145 \mathrm{x}$ & 0.896 \\
B. subtilis (UB_Bs1) & $1.9 \times 10^{9} \mathrm{cfu} / \mathrm{ml}$ & $\mathrm{y}=3.889+0.120 \mathrm{x}$ & 0.884 \\
Combination (UB_Pf1 + UB_Bs1) & $8.8 \times 10^{7} \mathrm{cfu} / \mathrm{ml}$ & $\mathrm{y}=3.463+0.193 \mathrm{x}$ & 0.919 \\
\hline
\end{tabular}


Patil, et al. (2000) stated that chitinolytic enzyme on bacteria is an extracellular enzyme, which takes nutrients and parasitism in controlling diseases biologically. Bacteria from Aeromonas, Alteromonas, Chromobacterium, Enterobacter, Ewingella, Pseudoalteromonas, Pseudomonas, Seratia, and Vibriogenuses are well-known bacteria that have chitinase (Gooday, 1994), Bacillus and Pyrococcus (Harman et al., 1993).

\section{The effect of bacterial isolates on median Le- thal Time $\left(\mathbf{L T}_{50}\right)$ P. coffeae}

The result of the probit analysis which was done to find out $\mathrm{LT}_{50}$ showed different values for each treatment. $\mathrm{LT}_{50}$ value and regression equation of each treatment was presented in Table 3 .

Data in Table 3 showed that $\mathrm{LT}_{50}$ value by the treatment UB_Pf1+UB_Bs1 $10^{13}$ was 13.211 hours. It indicated that combination of $P$. fluorescens and $B$. subtilis with colonies density $10^{13} \mathrm{cfu} /$ $\mathrm{ml}$ caused mortality to the testing nematode up to $50 \%$ within 13.211 hours. It implied that it required shorter time than the other treatments. The combination treatment of both bacteria, $\mathrm{LT}_{50}$ value by the treatment UB_Pf1+UB_Bs1 $10^{7}$ was 41.173 hours. It implied that combination of $P$. fluorescens and B. subtilis with colonies density $10^{7}$ $\mathrm{cfu} / \mathrm{ml}$ required 41.173 hours or 27.962 hours longer than the treatment with colonies density $10^{13}$ that caused $50 \%$ mortality of the testing nematode. Figure 6 presented the regression graphic on bacterial combination treatment of P. fluorescens and B. subtilis presenting that higher concentration leads to higher value of $\mathrm{LT}_{50}$.

The result of probit analysis on the application of P. fluorescens (UB_Pf1) and B. subtilis (UB_Bs1) also showed the same results as the combined treatments; the higher concentration of the colonies density applied, the shorter required time of $50 \%$ nematode mortality. It was proven on the application of $P$. fluorescens, the treatment of UB_Pf1 $10^{13}$ had LT $_{50}$ value 18.900 hours and UB_Pf1 $10^{7}$ with the lowest colonies density had $\mathrm{LT}_{50} 52.001$ hours. As well as $B$ subtilis, UB_Bs1 $10^{13}$ had $\mathrm{LT}_{50} 23.861$ hours and $\mathrm{LT}_{50}$ value with UB_Bs1 $10^{7}$ was 50.994 hours.

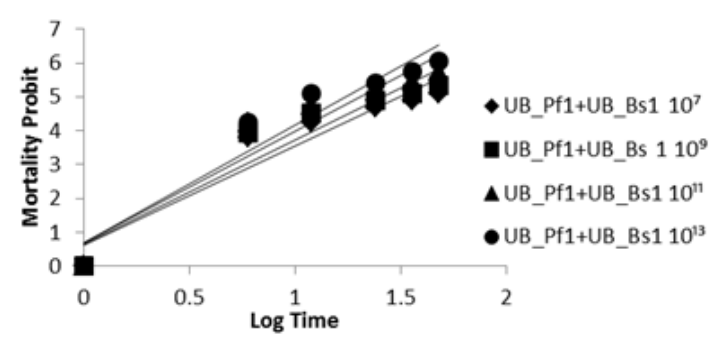

Figure 6. Correlation between time and nematode mortality (Combination)

Based on the result, it can be concluded that the bacterial colonies density on all treatments and $\mathrm{LT}_{50}$ value have positive correlation, in which higher concentration of the bacterial colonies density would shorten the required time to reach mortality up to $50 \%$. In addition, it implies that higher concentration of colonies densities shows that the bacteria would be more toxic. Besides, shorter time required by the bacteria to cause mortality on the testing nematode shows that the bacteria is more toxic than the application of other bacteria, which requires longer time to cause $50 \%$ mortality of testing nematode. The correlation can be clearly seen on regression graphic in Figure 7 and Figure 8.

Pseudomonas of fluorescens group is one of bacterial group, which is mostly learnt as bioagent controller. The bacteria have a combination of effective bio controlling mechanisms. Pseudomonas produces some secondary metabolites with antimicrobial activities to other bacteria and

Table 3. $\mathrm{LT}_{50}$ value on $P$. coffeae nematode mortality

\begin{tabular}{|c|c|c|c|}
\hline Treatments & $\mathrm{LT}_{50}$ value & $\begin{array}{l}\text { Regression equa- } \\
\text { tion }\end{array}$ & $\mathrm{R}^{2}$ \\
\hline UB_Pf1 $10^{7}$ & 52.001 hours & $y=2.485+1.465 x$ & 0.912 \\
\hline UB_Pf1 $10^{9}$ & 43.856 hours & $y=2.590+1.468 x$ & 0.910 \\
\hline UB_Pf1 $10^{11}$ & 22.721 hours & $y=2.791+1.629 x$ & 0.915 \\
\hline UB_Pf1 $10^{13}$ & 18.900 hours & $y=2.864+1.674 x$ & 0.915 \\
\hline UB_Bs1 $10^{7}$ & 50.994 hours & $y=2.215+1.631 x$ & 0.935 \\
\hline UB_Bs1 $10^{9}$ & 40.638 hours & $y=2.411+1.609 x$ & 0.943 \\
\hline UB_Bs1 $10^{11}$ & 28.505 hours & $y=2.786+1.522 x$ & 0.910 \\
\hline UB_Bs1 $10^{13}$ & 23.861 hours & $y=2.823+1.580 x$ & 0.911 \\
\hline UB_Pf1+ UB_Bs1 $10^{7}$ & 41.173 hours & $y=2.703+1.423 x$ & 0.907 \\
\hline UB_Pf1+ UB_Bs1 $10^{9}$ & 28.791 hours & $\mathrm{y}=2.854+1.471 \mathrm{x}$ & 0.907 \\
\hline UB_Pf1+ UB_Bs1 $10^{11}$ & 17.575 hours & $y=2.997+1.609 x$ & 0.909 \\
\hline UB_Pf1+ UB_Bs1 $10^{13}$ & 13.211 hours & $\mathrm{y}=2.937+1.840 \mathrm{x}$ & 0.920 \\
\hline
\end{tabular}


pathogens. Besides, the bacteria could inhibit the pathogen's growth by limiting the use of iron in the soil, which utilizing the resulted siderophore (Duijff et al., 1993; Duffy \& Defago, 1999).

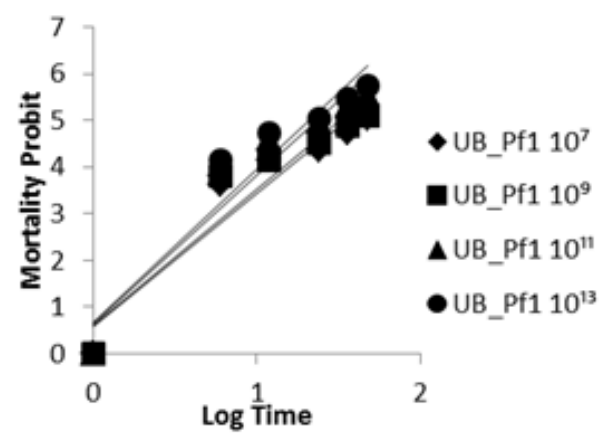

Figure 7. Correlation between time

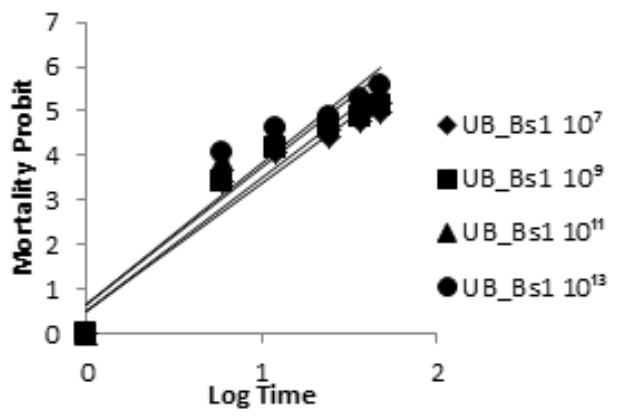

Figure 8. Correlation between time and nematoda mortality (P. fluorescens) nematoda mortality (B. subtilis)

Gokte \& Swarup (1988) reported that $B$ subtilis, B. cereus, and B. pumilus could inhibit larvaside activities on second juvenile (J2) Meloidogyne incognita in vitro. Based on result of the experiment in pot, it showed that reduced development of $M$. incognita in tomato by the application of B.subtilis. It is reported that this bacteria are potential to control some parasitic nematodes, including Meloidogyne spp.

\section{CONCLUSIONS}

The combined treatment of bacterial isolates $P$. fluorescens (Ub_Pf1) and B. subtilis (UB_Bs1) provides better results than single application with $\mathrm{LC}_{50}$ value $\left(8.8 \times 10^{7} \mathrm{cfu} / \mathrm{ml}\right)$. The combined treatment of UB_Pf1+UB_Bs1 with colonies density $10^{13} \mathrm{cfu} / \mathrm{ml}$ can kill $50 \%$ nematode in the shortest time with $\mathrm{LT}_{50}$ value (13.211 hours) and treatment UB_Pf1 with colonies density $10^{7} \mathrm{cfu} /$ $\mathrm{ml}$ requires the longest killing time of $50 \%$ nematode with the $\mathrm{LT}_{50}$ value (52.001 hours).

\section{ACKNOWLEDGEMENT}

The researchers would like to express their gratitude and great appreciation to the Agricultural Human Resources Development Institute (BPSDMP) and Estate Corps Regional Center of Seed and Protection (BBPPTP) Surabaya for their assistances during this research was conducted.

\section{REFERENCES}

Duffy, B. K. \& G. Defago. (1999). Environmental Factors Modulating Antibiotic and Siderophore Biosynthesis by Pseudomonas fluorescens Biocontrol Strains. App. Env. Microb, 65(6), 2429-2438.

Duijff, B. J., Meijer, J. W., Bakker, P. A. H. M. \& Schippers, B. (1993). Siderophoremediated Competition for Iron and Induced Resistance in The Suppression of Fusarium Wilt of Carnation by Fluorescent Pseudomonas spp. Netherlands Journal of Plant Pathology, 99(5-6), 277-289.

Emmert, E. A. B. \& Handelsman, J. (1999). Biocontrol of Plant Disease: a (Gram +) Positive Perspective. FEMS Microbiol Lett, 171(1), 1-9.

Gokte, N. \& Swarup, G. (1988). On the Potential of Some Bacterial Biocides Against Root-Knot and Cyst Nematodes. Indian Journal of Nematology, 18(1), 152-153.

Gooday, G. W. (1994). Physiology of Microbial Degradation of Chitin and Chitosan. in Ratledge C, editor. Biochemistry of Microbial Degradation. Netherlands: Kluwer Academic Publ.

Harman, G. E., Hayes, C. K., Lorito, M., Broadway, R. M., Di Pietro, A., Peterbauer, C., \& Tronsmo, A. (1993). Chitinolytic Enzymes of Trichoderma harzianum: Purification of Chitobiosidase and Endochitinase. Phytopathology, 83(3), 313-318.

Harni, R. \& Khaerati. (2013). Evaluasi Bakteri endofit untuk Pengendalian Nematoda Pratylenchus coffeae pada Tanaman Kopi. Buletin Ristri, 4(2), 109-116.

Jetiyanon, K., \& Kloepper, J. W. (2002). Mixtures of Plant Growth-Promoting Rhizobacteria for Induction of Systemic Resistance Againts Multiple Plant Diseases. Biol. Control, 24(3), 285-291.

Kloepper, J. \& Ryu, C. (2006). Bacterial Endophytes as Elicitors of Induced Systemic Resistance. in Microbial Root Endophytes, eds. Schulz, B., C. Boyle, T. Siebern. Springer-Verlag, Heildelberg.

Krebs, B., B., Hoeding, S., Kuebart, M. A., Workie, H., Junge, G., Schmiedeknecht, R., Grosch, H., Bochow, \& M. Havesi. (1998). Use of Bacillus subtilis as Biocontrol Agent: Activities and Characterization of Bacillus subtilis Strain. Zeitschrift Pflanzenkrankh Pflanzenschutz, 105, 181-197.

Loof, P. A. A. (1949). The Family Pratylenchidae .Thorne. in William R Nickle (ed) 1991. Manual of agriculture Nematology. Mercel Dekker, Inc New York.

Mullin, P. (2000). Photo Gallery Pratylenchus coffeae 
Presti Mardiyani Purwaningtyas, et al. / Biosaintifika 8 (3) (2016) 286-293

Konza Prairie. Retrieved from http://nematode.unl.edu/pracoff.htm

Siddiqui, Z. A. \& Mahmood, I. (1999). Role of Bacteria in The Management of Plant Parasitic Nematodes (a review). Bioresource Technol, 69(2), 167-179.

Siddiqui, M. R. (1972). Pratylenchus coffeae CIH. Description of Plant Parasitic Nematodes Set 1.6. Wallingford UK. CAB International: 3
Patil, R. S., Ghormade V., \& M. V. Deshpande. (2000). Chitinolytic Enzymes: An Exploration. Enzym and Microbial Technology, 26(7), 473-483.

Wiryadiputra, S. (1998). Pengelolaan Nematoda Parasit pada Tanaman Kopi di Indonesia. Kumpulan Materi Pelatihan Pengelolaan Organisme Pengganggu Tanaman Kopi No. Seri 017PL T05.98. Pusat Penelitian Kopi dan Kakao. Indonesian Coffee and Cocoa Research Institute: 1-15. 